\title{
$[3]$
}

\section{The Creative Individual in the World of the !Kung San}

\author{
Marjorie Shostak
}

Prophets and artists tend to be liminal and marginal people, "edgemen," who strive with a passionate sincerity to rid themselves of the cliché associated with status incumbency and role-playing and to enter into vital relations with other men in fact or imagination.

-Victor Turner

Art is the means whereby a healthy society manages to put to a constructive use man's seemingly least socializable impulses, and even to augment their ultimate intensity, by placing at their disposal the vast resources of culture, thereby making them both expressible and culturally productive.

—George Devereux

The !Kung San living on the northern fringe of the Kalahari Desert in Botswana and Namibia in southern Africa are probably the most well-researched hunting and gathering society in the anthropological literature. A multitude of research projects have described the !Kung's subsistence ecology, kinship and social structure, demography, population genetics, health, infant care and child training practices, and systems of belief and religious orientation. My own research conducted during approximately two-and-a-half years of field work focused on 
the psychological makeup of the individual as expressed in the oral life history.

Despite what might appear to be an enviable data base, little of it relates to the creative realm. A few outstanding efforts do exist, however: a detailed thesis on !Kung music (England 1968), an analysis of the compositions of a !Kung musician (Biesele 1976) discussed in the latter part of this essay, and some exploratory material on bead design and style (Shostak 1976). Less directly concerned with creativity, but indirectly relevant, is research on the religious realm (Lee 1968; Marshall 1976; Katz 1982) and on !Kung oral traditions (Biesele 1975).

Exploring what creativity means to the !Kung and identifying their more accomplished creative people is nevertheless a tricky task-and not because !Kung artists are not well represented. They are-primarily as musicians, healers, bead-weavers and storytellers. They are the ones who tell and retell the great myths, capturing the nuances of incest, murder, revenge and especially, the war between the sexes that abound in this oral tradition; they sing songs of longing and pain, their voices blending into the fabric of the night air; they heal the sick by uncovering hidden wishes and fears thought to interfere with health; and, exercising their imagination and skill, they create intricate, beautiful bead-weavings.

The !Kung value their artists, for without them, !Kung culture would stagnate: old songs, old renderings of stories, well-known events in the spirit world and bead designs would cease to excite. But their society is also staunchly egalitarian, exerting a strong social pressure against anyone rising in status above others. This attitude can create problems for!Kung artists who, by the sheer power and idiosyncratic nature of their creative expression, are inevitably set apart (at least in relation to that expression). Considerable tension, therefore, exists between encouraging the individual voice of the artist and discouraging an aura of superiority. In order for creative expression to flourish, the protocol followed by the artist must be comparable to that of others who succeed (such as a talented hunter): eschew all appearance of selfimportance or expectation of special status accruing from success.

The form these cultural requirements take, however, is not censorship. A popular misconception that small-scale communities demand greater conformity in individuality and creative expression than larger-scale societies finds no validation here. Indeed, the very smallness of !Kung society allows for considerable tolerance of individual differences. People have personal space, literally and figuratively, to 
be themselves. The expectation-even requirement-that individuals contribute to the culture is reflected in a variety of norms (such as the healing dance songs where everyone-from the most gifted to the least talented musician-improvises on standard melodies).

This delicate balance, deftly handled by the !Kung, is troublesome to an outsider gauche enough to inquire who might be the best artists in any one of a variety of !Kung expressive forms. Embarrassment for a person of such poor judgment who asks such an indelicate question is the initial (silent) response; then follows an answer in which all the names of those who participate in that expressive activity are included—offered in no particular order. To rank them would be bad manners.

I confronted this attitude during my second field trip (1975) when I asked people to judge photographs of bead-weavings I had collected during my first field trip (1969-71). Of two dozen photographs I brought with me, a small number reflected high artistic accomplishment-as had been recognized by curators at the Museum of Primitive Art (now part of New York's Metropolitan Museum of Art), where files on the bead-weavings were established, and by curators of a variety of other exhibitions. I had wanted to see how bead-weavers and those who didn't weave among the !Kung would rank the various pieces, especially these most impressive ones.

Since the bead-weavings had originally been collected in different villages and four years had intervened between field trips, I assumed that it would be easy to generate discussions of the beaded works from a purely aesthetic point of view. But an overwhelming reluctance to rank continued to prevail, whether discussed with an individual or with a group. It was not that judgments could not be made: one artist was willing to discuss the superiority of some of the weavings. She also acknowledged in private what I already believed: that she was the best (or, at least, one of the best) among those whose work I had followed. She would never say this to the others, of course, but within herself she knew.

Music, healing, bead-weaving, storytelling and fortune-telling (throwing leather discs and interpreting the resulting pattern) are the most typical avenues of creative expression. Etching on ostrich eggshell water containers or pieces of wood is traditionally less common (except, more recently, for the tourist trade). Healing is primarily the realm of men and bead-weaving the exclusive province of women, but expression in music and storytelling is generally exercised by anyone 
so inclined. Except for healing (which usually takes place during a medicinal ceremony known to anthropologists as a trance dance), creative expression takes place almost anywhere, during any segment of the day, when time and temperament prevail.

My work led me to interview a number of creative individuals. This essay explores some of the issues concerning the position of artists in !Kung society-the avenues available to them as they negotiate the conflicting demands of self and society, and the nature and content of their creative works. The concept of artists as "liminal" figures (Turner 1969) is valuable to this discussion, as is George Devereux's concept of art as "the harmless social safety valve for the expression of that which is taboo" (Devereux 1961).

My discussion centers on the lives of three creative !Kung individuals: Jimmy, a brilliant musician in his late twenties, who, over a period of years created a thumb piano repertoire that was subsequently adopted by a large percentage of the population; N!ukha, a woman healer in her early forties, who is a pioneer in the new women's drum dance which has increasingly given women a more direct and significant role in healing; and Hwan//a, a woman composer, singer, and bead design artist in her early thirties, whose art plays a more private but very crucial role in her life.

\section{Jimmy}

As traditional !Kung musical instruments are made of natural materials, it was only after a critical amount of metal became available that the metal-key Bantu instrument, the thumb piano or mbira, was adopted into !Kung musical culture. At the time of my first field trip in 1969, the instrument had been in the study area, Dobe, for about ten years. Younger children, adolescents, and young adults played it more frequently than older people, who preferred more traditional music.

Interested in learning the captivating rhythms and melodies that so often filled the air, I went among the young to learn their songs. The name "Jimmy" came up repeatedly. "This is Jimmy's music, Jimmy's compositions," they would say. And not just at Dobe. "Jimmy's" songs were being played everywhere I went.

Jimmy was a man in his late twenties, married with one child. Sullen and outcast in manner, he explained that no one liked him, which, 


\section{Marjorie Shostak}

given his difficult character, did not seem surprising. Yet when he played, everyone listened. The power of his music affected them. So, too, did his clairvoyance when he entered trance, which he accomplished while playing the thumb piano, instead of during the more traditional healing dance. No one before Jimmy or since has been able to do that. His unusual musical abilities as well as his ambiguous status within the culture made me curious. When I finally interviewed him I asked about his view of himself, his involvement with the thumb piano, and his battles with the world of the spirits.

When Jimmy was about eight years old, he experienced the first of many bouts with extreme illness. In this initial episode, his sickness stayed from one rainy season to the next. "All the !Kung healers tried to cure me, but nothing happened." It was the same when a Bantu healer tried. Then he had a dream in which God came to him. God told him, "Pick up the thumb piano and play." He had never played the instrument before; yet, "I just played." After that the sickness went away.

He was around fifteen at the time of his next encounter. Again, it was the rainy season. Suddenly, there was a clap of thunder, "so loud" and a bolt of lightning "so powerful" that it "picked me up and threw me against the back of my hut. The same clap of thunder made the tree behind my hut crack and fall. It killed four cows." (This incident was corroborated by another man who had been in the hut at the same time and who described Jimmy as having been hit by lightning; Biesele 1976.) This event was followed by a convalescence that lasted around eight months; he had a number of broken ribs, as well as injuries to his lower back and chest. "I stayed in the house the whole time and didn't sit with any woman except my mother."

His health returned only to be forfeited again, this time directly through "God's agency." He was near a well, pouring water into a trough. He spilled some water, slipped, and fell into the well. "I was flying down the well very far ... when God saw me and saved me. He turned me around so my feet hit the water first." When he hit, he momentarily lost consciousness. When he regained it, he grabbed the side of the well and called to others to throw down a chain and bucket. $\mathrm{He}$ got out and lay on the sand, sick. That's when God came to him and told him, once again, to play the thumb piano. He started to play and played beautifully. God then told him that He himself, not a !Kung, had given birth to Jimmy. He confirmed that everyone, except Jimmy's 
mother and younger sister, hated him. "Yes. People like me if I play ... but if I live with them long, they don't like me at all."

Jimmy married some time later, but within the year, a new sickness entered his life.. This time God informed him that his wife had taken a lover; Jimmy later found the couple together. Not long after, his wife had a child (who lived only three days) by her lover, a fact revealed to Jimmy by God. Jimmy brought the issue to tribal court. The lover was fined and gave Jimmy seven goats, but the situation did not change. In fact, not long after, the lover tried to poison Jimmy: he poured evil medicine through the grass of his hut while Jimmy slept. The medicine fell on his shoulder. While Jimmy was playing the thumb piano, God revealed the lover's role in this new sickness. Jimmy asked another healer to make medicinal cuts on him; within a few months he was better. Barely three days later, his wife complained of a headache. That very night she died. Some time later, Jimmy married again and had a daughter with his new wife. He has not been ill since.

Jimmy acquired his Western name after working on a Bantu cattle post, an experience quite common for younger!Kung men. Yet, he is one of very few in the population to be known by such a name; clearly, both he and others find it fitting. His name reflects a status that is tentative, somewhat foreign and removed; yet, as are most outsiders with such names, he is also elevated and respected. "Crazy Jimmy," as he is often referred to, lives in a bush camp with his immediate family, a few miles apart from a more established group of villages. As such, he is physically and socially separate.

Those of his compositions adopted by others are his shorter songs, ones without words. The music he plays for himself, however, is sometimes expressed in an unintelligible tongue; at other times its language is clear, picturing him as persecuted and unique. He often sings of the fear and the allure of death:

\footnotetext{
"Where will I hide from God's death?

The day when God speaks where will I be. . .

The year of my death is known,

The day of my death is known."

"I am the one whom death visits first,

Then it passes by me and goes to all people."

"Death Year is upon me...."
} 
He makes reference to his exalted position as the offspring of God and to God's having given him his musical gift:

"I am God's son....."

"God spoke, telling me to take up

These metal bits and this scrap of wood

And with them to sing."

"I speak to God in his speech

I cry with God

I tell him to lift me from the earth

God deceives me, yes."

He also sings of his misery:

"Yesterday we sat together and spoke

You said that I was your child.

This piece of wood you gave and said it might be mine.

Why have you changed your mind and now you wish to kill me."

"You said I should sing what we two own between us: our song."

"You, God, said

These bits of metal,

These scraps of wood

Would give me life.

But it was a trick:

My people are dying

And I will die."

"Terrible God deceives, torments.

God's arms descend into my fingers."

"Everyone stop tormenting me.

Stop bringing me misery

Don't bring me any more pain."

[Biesele 1976]

Jimmy embodies the contradictions of life that his music, somehow, both expresses and resolves, touching upon themes that deeply touch those who hear him play. As such, his art expresses the deepest of wishes and fears, ones that have few other culturally sanctioned outlets. 


\section{N!ukha}

N!ukha is Jimmy's half sister. She comes from a long line of medicinal healers; her mother and father and their respective parents all had the ability to lay on hands and cure. Her own daughter developed, in her early twenties, a form of psychosis that was labeled schizophrenia by a visiting medical team, but other researchers hypothesized it may have been manic-depressive illness.

Unlike Jimmy, and despite her daughter's illness, N!ukha is not an outcast. She lives in a large !Kung village where she is caught up in an active social world. She has three living children all with different fathers. Her first daughter was conceived with her first husband; a second daughter was conceived with her third husband; and a son was conceived with a lover. All three of her husbands are deceased.

After years of being uninvolved in spiritual exploration, N!ukha began to put her energies into healing and earned a reputation as a powerful shaman. She had the ability, not only to enter altered states of consciousness, but to actually lay on hands and heal. Just months after the death of her third husband, I interviewed her about her life and about her experience with healing.

!Kung healers play two fundamental roles. The first, while in trance, is to "discover" the underlying cause of disease. Sometimes "discovery" involves referring to an "obvious" problem in the ill person's life and identifying it as a causal agent. More often, however, the healer must articulate a more subtle conflict within the individual and, by revealing it, help destroy its power to fuel illness. This analysis requires psychological insight, imagination, and physical stamina. Different healers may uncover different causal factors.

The !Kung description of how the healer's soul leaves the body to commune with the world of the spirits is a fitting metaphor for the creative process: peeling off successive layers of consciousness so that the soul is free to wander in the midst of psychic phenomena; then the pieces of the pattern may make sense. For it is only after the healer "sees" the cause (or causes) of a person's illness that the second role-laying on hands and "pulling out" illness-can begin. Each "cure" is a testament to the healer's ability to "listen" to the inner, intuitive voice. Once the pattern is articulated, the success of the cure is measured in its power to weaken the force that subconscious psychological factors play in predisposing a person to disease.

Insofar as the interpretation of illness reflects the ability to delve 
into this subterranean world of the human psyche, to articulate underlying wishes and fears, and to create patterns of meaning and "truth" for the community, this process is a kind of primal creative expression. This is particularly true for women who, traditionally, were less involved than men in the trance experience and who followed a more individualized and circuitous career. According to N!ukha, her own experience in this realm started when she was quite young. She was around eight years old when her mother first introduced her to an alleged herbal hallucinogen, the !gwa root, to teach her about different states of consciousness. Her mother directed her through this experience about four times. N!ukha experienced strange feelings in her stomach and in her back, and she threw up.

Not long after, she went gathering with her mother and saw honey on the ground, as though set down by a person. She looked for the tree it might have come from, or for the tracks of the person who might have gotten it, but did not see anything. She called for her mother, who explained that the honey had come from God, and that she should eat it. They both ate, leaving some behind. Soon after, N!ukha became nauseous and threw up. Her body shook and trembled just as it had done with the ! gwa root. Her mother said that this was good; she wanted N!ukha to have strong medicine.

After that, whenever there were curing dances, her mother tutored her. Within a few years she was able to enter a light trance state known as tada. It was painful and frightened her, although she had already achieved some power. One time, the pain was so great that her mother told her she should stop her apprenticeship for a while. After that she went to very few dances; she was afraid of the sensations, which she described as, "Your insides are like thorns."

Then, one night, while asleep, she saw God. He was on a horse with white in the middle of its face. He sat in a chair and laughed at her fear. He told her that when she was older, she would have very powerful medicine. She cried out and when her mother heard, she knew what had happened. She told N!ukha not to be afraid. "God just wanted to see you."

God came to her again, another night, and asked why she was not doing what she was supposed to do: learning to trance. She trembled and cried; her back and stomach felt intense pain. Her mother woke and rubbed her stomach until the pain went away. Then she slept. The next morning her mother told people to have a medicine dance so she could help her daughter. They sang the traditional songs while 
her mother carried N!ukha around on her back. N!ukha felt the medicine surging within her again, and it hurt. When her mother put her down, she threw up. Soon she was tired and they stopped. But she was still afraid; even though her mother wanted her to learn more, she refused.

Her next memory, of a curing dance, dates from when she was around fourteen. Although she had not eaten ! gwa for a number of years, the sensations of the spiritual forces once again "struck" her. People said that she could become a powerful healer, but she remained aloof from trancing for years. It was only after her first child was born that she went back to it, because "childbirth hurts so much more than medicine. . . . A child's pain kills you and medicine doesn't." Now past the age of childbearing, she not only "sees" sickness, she has the power to lay on hands and cure: a spiritual and physical purging-a "pulling out" of sickness. Unlike other powerful healers, she does not see the gods. When she goes into trance, "Only my mother helps me; she tells me what is wrong with people."

Since she started laying on hands, people have come to her to be cured. But she will not trance during the men's ceremonial dance; because other women healers rarely do that. "I want to do what most other women do." She trusts a few men who have helped her become stronger, but she worries that others might steal her powers, leaving her without strength. She lets the more experienced male healers cure first, even though she thinks her healing powers are as strong. If their cure does not work, then she tries. People might laugh at her, she explains. "When men are not successful in curing, they aren't afraid of being laughed at... because they are men. Everyone knows that women are without strength. Things defeat them all the time.... If it's spiritual powers, people will laugh at you for thinking that you have medicine."

Another reason she lets the experienced medicine men try first is to avoid being accused of interfering. "Sometimes God kills someone. He refuses to help the medicine man ... but God usually helps [me] in the end." She waits and watches. Then she lays on hands and the person gets better. She feels that she is more successful than most of the male healers, and "I may even be more powerful." She does concede, however, that one or two men may be even more powerful than she. But she is quick to point out that she learned to cure long after they did. Because, unlike women, men do not have to put aside their apprenticeship to have babies. 
N!uhka claims she has cured many people, impressing them with the strength of her spiritual powers. Once, for example, there were huge rain clouds nearby. She told everyone that the clouds would not come their way, that they would pass. Others did not believe her. She recalls, "Because they refused to believe [me], the clouds came." It rained heavily that night and the people asked her to make it go away. At first, she refused because "they had not listened to me." But then, she thought "of the children." She spoke to God and the rain left. When God heard what had happened, he said that the others should never dispute her words again. The next morning she told them, "If you do not listen to me, God will bring lightning and everyone will die."

Her relationship to God was not always congenial. Once she angered God and became so sick that she almost died. This happened soon after her husband took her to live at another village, leaving her father behind. Once she had settled there, God visited her. He asked how she was, "just like an ordinary greeting." He wanted to know if she had come to live there. When she told him she had, he said he would kill her. She became very sick; her "heart was like it was swollen." Other healers tried to help, but they could not "see" the cause of the illness. She felt herself drifting away, as a feeling like sleep came over her.

While she lay there, God came to her again. He told her she should not have left the other village. He touched her chest and she threw up all night. She told her husband what had happened, but he did not want to leave, so someone else brought her back. The night she arrived home, God came to her again and thanked her. He blamed her husband, saying it was his fault; and he warned her that, if she ever went back to the other village, "it will be like you are about to sleep, but you will die." She did not go back and soon was better. Her relationship to God has been pleasant ever since. "When I see him, he's happy with me. He greets me when he arrives, and when he leaves."

Unlike her half brother Jimmy, N!ukha does not exude a creative force of such great magnitude that she is set apart from others. Indeed, other than the problems associated with her daughter's illness, she participates in the nexus of !Kung life. True, there is much gossip about her, especially about her having buried three husbands; and there is no doubt that she strives to dampen her effervescent personality, to be more like everyone else. Yet, she is also clearly willing to 
explore the art of healing, one in which few women participate. In so doing she challenges the more established male healers, offering, in the least threatening way she knows how, her alternative brand of medicine.

As with psychoanalytic training, in which the initiate undergoes self-analysis, !Kung healers are also most effective after having delved into the forces working upon their own lives. N!ukha's own "selfanalysis" reflects a recognition of the depth of her connection to her parents, especially to her mother (even as it put her at odds with others, including her husband). Whether her gift is explained as God's voice or her own, her willingness to tap these psychic resources and to use intuition and perception makes her "cures" daring and fuels her creative personality. There is no clear theoretical structure handed down for generations by practitioners as in psychoanalysis. A framework with broad outlines does exist, but it leaves ample room for $\mathrm{N}$ !ukha's imagination, especially since her role is a fairly new one for women. Ultimately, she must rely on her own vision of the spiritual forces that cause illness and suffering-to uncover what Devereux called the "eternal nature of the eternally ungratified and therefore eternally challenging wishes underlying it" (Devereux 1961). In a way she is a composer of fictions with psychological insight and moral purpose, much as she is a medical practitioner, and her work gives life to the cliché that art can heal.

\section{Hwan//a}

Hwan//a is a woman in her early thirties who does elaborate beadweavings - one of the few mediums available to the !Kung for the expression of visual form-and who also writes songs and plays musical instruments. Born into the mainstream of traditional !Kung life, she now is something of an outsider. When young and beautiful and full of a sparkling spirit even now in ample evidence, she attracted the handsome son of the local Bantu headman. The ensuing romance was passionate and intense, and soon they married. Yet, as the years passed, Hwan//a had only one pregnancy, and that ended in miscarriage. Probably because of the strength of her husband's love, he never did what most other Bantu men do with a !Kung wife: marry her as a second wife, or bring in another woman to be her cowife. After years 
of remaining childless, however, her husband did start a family-albeit an illegitimate one-with a Bantu woman living in a nearby village.

Hwan//a bemoans her misfortune, mourning the loss of the children she never had and the exclusive relationship she once had with her husband. No one, not even Hwan//a, completely faults her husbandboth the !Kung and the Bantu sanction polygyny-yet, jealousy, anger, and resentment still plague her. She wishes that he would end the marriage so that she could return to live with her mother and other relatives. But he will not agree to that. She wavers between thinking that this indicates the depth of his love for her, and thinking that he is using her, wanting a free servant to look after his cattle and household. She complains about how hard she works for him, that he is rarely there, and that he never gives her presents.

Yet Hwan//a's sorrow does constant battle with forces of play and delight. When energized, she can rivet all around her, be it while playing the tama melon tossing game or being a lead singer in the traditional healing dance. Her most impressive achievements, however, are when she sits by herself, singing songs she has composed or working out intricate patterns of bead-weavings, choosing colors and design with the skill of an accomplished artist.

I first met Hwan//a soon after her husband had his first child with his mistress. I included her in the life-history study I conducted with seven other women. Once this study was completed, I engaged her, along with others, to sew colorful trade beads. The format was headbands or pubic aprons (coverings worn in front of the genitals underneath a variety of leather skirts). None of the pieces was destined to be worn: these forms were chosen to conform to existing cultural patterns, but I thought of them as resembling blank canvases.

The details of the beadwork are not appropriate to review here, except to remark on the extraordinary creative accomplishments in Hwan//a's pieces. Abstractions called Zebra's Face or Starry Night boldly explored spatial planes and color. Sophisticated variations on a theme were worked out in a composition called Owl Eyes. Stripes rhythmically alternating with triangles (a motif of leaves on water) graciously spanned the breadth of a headband. And there were more.

Her musical talents as composer, singer, and musician were equally impressive, and much appreciated by those who clustered around her when she played. Her most haunting song (and my favorite), "Come here ... come here, little one of mine," is played on the thumb piano while variations on these words are sung. At times, the longing refers 
to the child she never had; then it changes color and the enchantress ever so gently calls to her lover. While others may enjoy her music, it is intensely private. Unlike Jimmy and N!ukha, she is seeking neither notoriety nor influence. She seems to be playing to, and for, herself.

\section{Conclusion}

The portraits of three individuals show a variety of modes of creative expression available in !Kung life as well as different levels of creative involvement. Jimmy, the farthest from the norm-perhaps even borderline in personality-is by far the most innovative. It is unclear whether he would actually want to alter his "outsider" position, since his fervent belief that he is the son of God as well as God's messenger precludes his reaching out to others as much as it distances them. People flock to hear him play and sing about his tortured life both in the "real" and in the "spirit" world, as much as they ask him to communicate with God about spiritual meddling in earthly concerns.

Jimmy knows, and everyone else agrees, that he is unusually gifted. Yet, unlike the negative feelings that sometimes attach to a successful hunter, gatherer, singer, dancer, healer, or musician-who must outwardly downplay his or her accomplishments-envy and scorn are allayed in Jimmy's case by the anguish and torment that pervade his life. Few could desire his less than appealing personality or his lot in life, even though his talent and music are striking. His isolation helps protect him from residual jealousies even as it helps him keep his paranoia and feelings of persecution in control. For Jimmy, creative expression is his life. That he occasionally receives presents for explaining the ways of the spirits, or for pleading with them for specific interventions, is a secondary gain.

N!ukha the healer and Hwan//a the musician and bead designer differ from Jimmy and from each other, offering alternative models of the creative individual in !Kung society. Despite the quirks in their life histories, they partake in the normal range of !Kung life and the avenues of creative expression they explore are trod by many. Creative expression does not rule their lives or define their selves with Jimmy's singleness of purpose. N!ukha excels in a public area usually the province of men; Hwan//a's expression is more private and internal.

Jimmy, N!ukha, and Hwan//a conform to Devereux's concept of the artist as articulator of the taboo, who turns raw feelings and submerged 
interpersonal connections into culturally acceptable expressions that touch upon psychic undercurrents in other people's lives. In terms of "liminal" personalities, Jimmy clearly fits Turner's model of the artist, but both N!ukha and Hwan//a could be considered liminal as well: N!ukha, with her closeness to mental illness (her schizophrenic daughter and "Crazy Jimmy," her half brother), her several marriages ending in the deaths of her husbands, and her willingness to do battle in a predominantly male domain; and Hwan//a, with her Bantu husband and her lack of children. Yet, their liminal position does not seem fundamental to their participation in !Kung creative life, nor to the tolerance accorded them by their society. In fact, contributions like N!ukha's in the spiritual realm are matched, if not to the same degree, at least in kind, by almost half the men and a small percentage of women. True, few people compose songs as Hwan//a does, but a great many do sing and play instruments. The same might be said of the sophisticated bead artistry that, although relatively new (glass beads have been unavailable in adequate supply until recently), still engages a large number of women doing thoughtful and original works.

It might come as a surprise, then, that of the large number of people participating in the creative realm, only a small percentage could be considered truly liminal. This conclusion underscores the relative lack of social restraints, both in physical movement and in personal expression. Males and females, together or apart, leave camp to gather or hunt, walking miles beyond the village and its constraints several times a week. Village life abounds with the ever-present sound of talkpeople expressing their point of view, often simultaneously. Individual differences in personality seem to thrive in this environment as does the tolerance for creative expression. Perhaps because no formal change of status ensues and few rewards are received, there is little advantage in being distinctive, other than for oneself. Thus, the egalitarian balance of !Kung society remains unthreatened by creative individuals.

In summary, then, creativity flourishes in !Kung life. There is little material incentive for its exercise, only the gain of the informal respect of others or the pleasure it gives the self. A "liminal" person may be more apt to find comfort in creative expression, but the tolerance and appreciation for the artist applies to those in the mainstream of !Kung life as well. Those who do participate in the creative realm-be it in music, in uncovering the workings of the spirit world, or in weaving stunning bead pieces - clearly fit Devereux's conception of the artist 
as one who transmutes painful or upsetting truths into beauty, tapping underlying themes that are at once basic and intense. At the same time, despite the prevalence of artistic expression among the !Kung, the lives described here also support Turner's view that the most extreme form of creative expression, as represented by Jimmy, may indeed require a truly and permanently liminal status. Whatever the personality of the artist and whatever form the creative energies take, the richness of their expressive life is itself a testament to the value the !Kung assign to this part of their experience.

\section{REFERENCES}

Biesele, Megan. 1975. "Folklore and Ritual of !Kung Hunter-Gatherers." 2 vols. Ph. D. diss., Harvard University.

1976. "Song Texts by the Master of Tricks: Kalahari San Thumb Piano Music." Botswana Notes and Records, vol. 7. Gaborone, Botswana.

Devereux, George. 1961. “Art and Mythology." In B. Kaplan, ed., Studying Personality Cross-Culturally. Evanston, Ill.: Row, Peterson. Pp. 361-86.

England, Nicholas. 1968. "Music among the Zu/wasi of South Western Africa and Botswana." Ph.D. diss., Harvard University.

Katz, Richard. 1982. Boiling Energy. Cambridge: Harvard University Press.

Lee, Richard. 1968. "The Sociology of !Kung Bushmen Trance Performances." In R. Prince, ed., Trance and Possession States. Montreal: Bucke Memorial Society.

Shostak, Marjorie. 1976. "Glass Beadwork of the !Kung of Northwestern Gaborone." Gaborone: The Botswana Society.

- 1981. Nisa: The Life and Words of a !Kung Woman. Cambridge: Harvard University Press.

Turner, Victor. 1969. The Ritual Process. Harmondsworth, England: Penguin Books. 